\title{
Annular alopecia areata: a morphologically rare variant
}

\author{
Manish Bansal, ${ }^{1}$ Ajit Kumar, ${ }^{1}$ Alka Bansal ${ }^{2}$
}

'Department of Dermatology and Venereology, Institute of Medical Sciences, Banaras Hindu University, Varanasi, Uttar Pradesh, India

${ }^{2}$ Department of Pathology, Swami Harshankaranand $J$ Hospital \& Research Center, Varanasi, Uttar Pradesh, India

\section{Correspondence to}

Dr Manish Bansal, manishderma@gmail.com

Accepted 25 September 2015

\section{DESCRIPTION}

A 17-year-old man presented with asymptomatic, recurrent patchy hair loss over his scalp for 5 years, which would resolve after treatment. There was no history of hair loss from other areas. The patient had no personal or family history of diabetes or thyroid disease. On examination, five non-scarring patches with alopecia of annular $(12 \times 10 \mathrm{~cm})$, circular, semilunar and linear morphology were present over scalp (figure 1). The rest of the mucocutaneous examination was normal. Complete blood count, serum blood sugar and thyroid profile were within normal limits. Potassium hydroxide examination and fungal culture taken from the lesions were negative. Histopathology showed an increased number of follicles in the catagen/telogen. The affected follicles showed mild perifollicular lymphocytic infiltrates around the bulbs and within the fibrous tracts (figure 2). Alopecia areata (AA) is the most common type of non-scarring alopecia involving the scalp and/or other areas of body hair. It is considered an autoimmune disease and associations are seen with thyroid disease, diabetes mellitus and vitiligo. Patchy AA is the most common form, and is usually circular or oval. Earlier authors have reported other patterns, such as

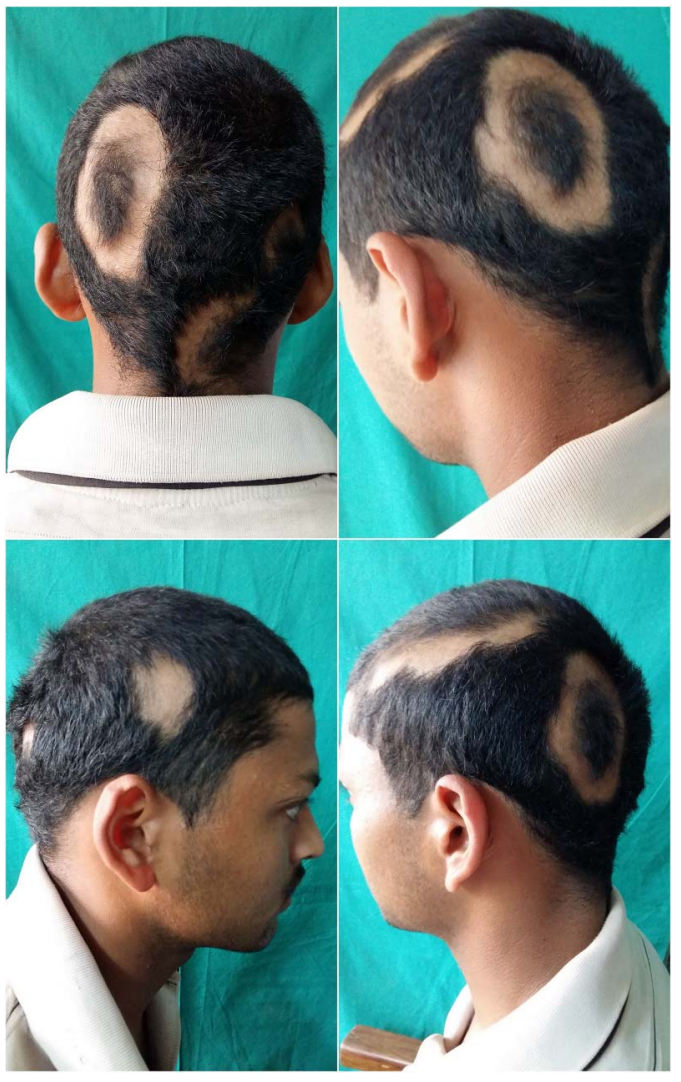

Figure 1 Clinical photographs showing non-scarring alopecia in annular, linear, semilunar and circular shapes.

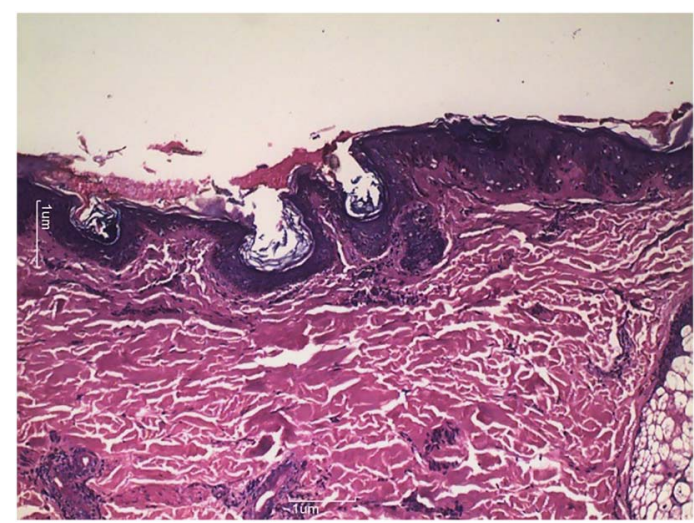

Figure 2 Photomicrograph showing hair follicles with perifollicular lymphocytic infiltrate (H\&E stain, $\times 40)$.

rectangular, associated with malignancies including diffuse large B cell lymphoma, ${ }^{1}$ and linear, which was described to be a variant of lupus profundus. ${ }^{2}$ Only two cases of annular AA have been reported in the literature so far. ${ }^{3}$ The treatment of AA depends on the area involved and mostly intralesional steroids are given for localised disease. The other autoimmune associations of the disease should always be ruled out. An annular pattern of AA is a rare morphological presentation despite having the same underlying pathogenesis and treatment as the others.

\section{Learning points}

- Alopecia areata (AA) is an autoimmune disease mediated by autoreactive T-cells against hair follicles.

- The scalp is the most common site. Patchy AA is the most common type and is usually circular or oval.

- Diagnosis is made clinically, but on histopathology, perifollicular infiltrates appear like 'a swarm of bees'.

Acknowledgements The authors thank Professor SS Pandey, Head of the Department, for helping them write this manuscript.

Competing interests None declared.

Patient consent Obtained.

Provenance and peer review Not commissioned; externally peer reviewed.

\section{REFERENCES}

1 Shin J, Jang HS, Cho SB. Rectangular-patterned occipital alopecia areata: a report of three cases. Int J Trichology 2012;4:164-6.

2 Rhee $\mathrm{CH}$, Kim SM, Kim MH, et al. Two cases of linear alopecia on the occipital scalp. Ann Dermatol 2009:21:159-63.

3 Bansal M, Manchanda K, Pandey SS. Annular alopecia areata: report of two cases. Int J Trichology 2013;5:91-3. 
Copyright 2015 BMJ Publishing Group. All rights reserved. For permission to reuse any of this content visit http://group.bmj.com/group/rights-licensing/permissions.

BMJ Case Report Fellows may re-use this article for personal use and teaching without any further permission.

Become a Fellow of BMJ Case Reports today and you can:

- Submit as many cases as you like

- Enjoy fast sympathetic peer review and rapid publication of accepted articles

- Access all the published articles

- Re-use any of the published material for personal use and teaching without further permission

For information on Institutional Fellowships contact consortiasales@bmjgroup.com

Visit casereports.bmj.com for more articles like this and to become a Fellow 